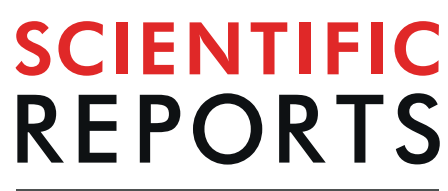

natureresearch

\title{
Rapid metabolism increases the level of 2,4-D resistance at high temperature in common waterhemp (Amaranthus tuberculatus)
}

\begin{abstract}
Chandrima Shyam ${ }^{1}$, Amit J. Jhala ${ }^{2}$, Greg Kruger ${ }^{2,3}$ \& Mithila Jugulam $\mathbb{1 D}^{1 *}$
Common waterhemp emerges throughout the crop growing season in the Midwestern United States, and as a result, the seedlings are exposed to a wide range of temperature regimes. Typically, 2,4-D is used in the Midwest to control winter annual broad-leaf weeds before planting soybean and in an early post-emergence application in corn and sorghum; however, the evolution of 2,4-D-resistant common waterhemp in several Midwestern states may limit the use of 2.4-D for controlling this problem weed. Moreover, temperature is one of the crucial factors affecting weed control efficacy of 2,4-D. This research investigated the effect of temperature on efficacy of 2,4-D to control 2,4-D susceptible (WHS) and -resistant (WHR) common waterhemp. Do se-response of WHS and WHR to 2,4-D was assessed at two temperature regimes, high $\left(H T ; 34 / 20^{\circ} \mathrm{C}, \mathrm{d} / \mathrm{n}\right)$ and low $\left(\mathrm{LT} ; 24 / 10^{\circ} \mathrm{C}, \mathrm{d} / \mathrm{n}\right)$. Whole plant dose response study indicated an increased level of 2,4-D resistance in WHR at HT compared to LT. Additional investigation of the physiological mechanism of this response indicated that both WHS and WHR common waterhemp plants rapidly metabolized ${ }^{14} \mathrm{C} 2,4-\mathrm{D}$ at HT compared to LT. In conclusion, a rapid metabolism of 2,4-D conferred increased level of resistance to 2,4-D in WHR at HT. Therefore, application of 2,4-D when temperatures are cooler can improve control of 2,4-D resistant common waterhemp.
\end{abstract}

Common waterhemp [Amaranthus tuberculatus (Moq.) Sauer] is one of the most troublesome weeds that can cause extensive yield loss in major agronomic crops in the Midwestern United States. Season-long interference of common waterhemp can result in up to $56 \%$ and $74 \%$ yield loss in soybean ${ }^{1}$ and corn $^{2}$, respectively. Biological characteristics of common waterhemp, such as continuous emergence pattern, high fecundity, and adaptability to diverse environment conditions make this species difficult to control. Moreover, the evolution of multiple herbicide resistance has reduced herbicide options for the management of common waterhemp. A synthetic auxinic herbicide (SAH), 2,4-dichloro-phenoxy acetic acid (2,4-D), has been a valuable post-emergence (POST) option to control many broadleaf weeds including common wateremp; however, the evolution of common waterhemp resistant to 2,4-D can affect the utility of 2,4-D-resistant corn and soybean. Common waterhemp resistant to 2,4-D was first documented in 2009 in $\mathrm{Nebraska}^{3}$, followed by Illinois ${ }^{4}$, and more recently in Missouri ${ }^{5}$. The WHR (2,4-D resistant common waterhemp) population from Nebraska is 8-10-fold resistant to 2,4-D compared to a known susceptible (WHS) population ${ }^{3}$. Further, a rapid metabolism of 2,4-D, possibly mediated by cytochrome P-450 monooxygenases, has been reported to confer resistance in this population ${ }^{6}$. Similarly, 2,4-D resistance in common waterhemp population from Missouri was also attributed to a rapid metabolism mediated by cytochrome P-450 monooxygenases ${ }^{5}$.

Reproductive success of common waterhemp is often attributed to its broader window of emergence ${ }^{7,8}$. Such emergence pattern demands a PRE (pre-emergence) followed by a POST herbicide program for effective control and to reduce crop yield loss ${ }^{9,10}$. Moreover, studies show increased ecological advantage to common waterhemp

${ }^{1}$ Department of Agronomy, Kansas State University, 2004 Throckmorton Plant Sciences Center, 1712 Claflin Road, Manhattan, KS, 66506, USA. 'Department of Agronomy and Horticulture, University of Nebraska-Lincoln, 202 Keim Hall, Lincoln, NE, 68583, USA. ${ }^{3}$ University of Nebraska-Lincoln, North Platte, NE, 69101, USA. *email: mithila@ksu.edu 


\begin{tabular}{|c|c|c|c|c|c|}
\hline \multirow[b]{2}{*}{ Population } & \multirow[b]{2}{*}{ Temperature $\left({ }^{\circ} \mathrm{C}\right)$} & \multirow{2}{*}{$\begin{array}{l}\text { Effective herbicide dose } \\
\mathrm{GR}_{50}\left(\mathrm{~g}_{\text {ae ha }}{ }^{-1}\right)\end{array}$} & \multirow{2}{*}{$\begin{array}{l}\text { Resistance } \\
\text { Index (RI) }\end{array}$} & \multicolumn{2}{|c|}{ Regression parameters } \\
\hline & & & & b & d \\
\hline \multirow{2}{*}{ WHS } & $24 / 10$ & $107( \pm 26)$ & - & $0.88( \pm 0.14)$ & $99.88( \pm 6.00)$ \\
\hline & $34 / 20$ & $178( \pm 43)$ & - & $0.76( \pm 0.11)$ & $101.27( \pm 5.80)$ \\
\hline \multirow{2}{*}{ WHR } & $24 / 10$ & $1001( \pm 237)$ & 9.35 & $0.81( \pm 0.14)$ & $100.39( \pm 5.95)$ \\
\hline & $34 / 20$ & $3696( \pm 1138)$ & 20.76 & $0.65( \pm 0.16)$ & $100.57( \pm 5.58)$ \\
\hline
\end{tabular}

Table 1. Regression parameters estimated from the whole-plant 2,4-D dose- response study based on dry shoot biomass of 2,4-D-susceptible (WHS) and -resistant (WHR) common waterhemp grown under low $\left(24 / 10^{\circ} \mathrm{C}\right.$, $\mathrm{d} / \mathrm{n})$ and high $\left(34 / 20^{\circ} \mathrm{C}, \mathrm{d} / \mathrm{n}\right)$ temperature regimes at 4 weeks after treatment (WAT). ${ }^{\mathrm{a}} \mathrm{Data}$ combined from two runs. ${ }^{\mathrm{b}} \mathrm{GR}_{50}$ is the effective $2,4-\mathrm{D}$ doses $\left(\mathrm{g} \mathrm{ae} \mathrm{ha}^{-1}\right)$ required for $50 \%$ reduction in shoot dry biomass. ${ }^{\mathrm{c}} \mathrm{RI}$ is calculated as a ratio of $\mathrm{GR}_{50}$ ofthe WHR population to $\mathrm{GR}_{50}$ of the WHS population. ${ }^{c}$ Values in parenthesis are standard error of mean.

cohorts emerging early in the season than later ${ }^{11}$. Temperature is one of the critical environmental factors that can fluctuate throughout the growing season. In Kansas, the early emerging waterhemp is exposed to a lower day/night temperature ranging from $18.4-29.0 / 3.1-20.6^{\circ} \mathrm{C}\left(\mathrm{d} / \mathrm{n}\right.$; average $\left.24.7 / 11.6^{\circ} \mathrm{C}\right)$, while late in the season diurnal temperatures ranges from $28.2-40.5 / 15.1-27.1^{\circ} \mathrm{C}\left(\mathrm{d} / \mathrm{n} \text {; average } 34 / 21.2^{\circ} \mathrm{C}\right)^{12}$. Temperature can affect the growth and development of common waterhemp ${ }^{13}$, which in turn can influence the efficacy of POST herbicide application ${ }^{14}$. Below optimal efficacy of POST-herbicide not only results in reduced weed control but can also select resistant biotypes due to increasing chances of survival and seed production.

$2,4-\mathrm{D}$, is widely used for managing dicotyledonous weeds in several crops and non-crop areas. Additionally, 2,4-D choline/glyphosate/glufosinate-resistant corn (Enlist ${ }^{\mathrm{TM}}$ corn) is commercially available from 2018 growing season in the United States and 2,4-D- choline/glyphosate/glufosinate-resistant soybean (Enlist ${ }^{\mathrm{TM}}$ soybean) is likely to be commercially available in the near future. In sensitive dicotyledonous weeds, 2,4-D is absorbed through root, stem, and leaves and gradually translocates systemically to meristems ${ }^{15}$. Plant species tolerant to 2,4-D naturally degrade this herbicide into inactive metabolites, thus preventing the active ingredient to translocate further ${ }^{16}$. For instance, in corn, 2,4-D is metabolized via ring hydroxylation mediated by cytochrome P-450 monooxygenases ${ }^{17,18}$. Similar to monocotyledonous weeds, in many 2,4-D-resistant dicotyledonous weeds such as corn poppy (Papavar rhoeas $)^{19}$, common waterhemp ${ }^{5,6}$, degradation was possibly mediated by cytochrome P-450 monooxygenases. Apart from metabolism, reduced absorption and/or translocation of 2,4-D have also been found to bestow 2,4-D resistance in several dicotyledonous weeds such as corn poppy ${ }^{20}$, prickly lettuce (Lactuca serriola) $)^{21}$ and wild radish (Raphanus raphanistrum) $)^{22}$.

The effect of temperature on herbicide efficacy often vary depending on weed species and herbicide site of action. For example, Ganie et al. ${ }^{23}$ found that efficacy of 2,4-D was improved to control giant ragweed (Ambrosia trifida) and common ragweed (Ambrosia artemisiifolia) at temperature $29 / 17^{\circ} \mathrm{C}, \mathrm{d} / \mathrm{n}$ due to increased $2,4-\mathrm{D}$ translocation compared to $20 / 11^{\circ} \mathrm{C}, \mathrm{d} / \mathrm{n}$ temperature. In contrast, Ou et al..$^{24}$ reported reduced control of kochia (Kochia scoparia) at a higher temperature $\left(32.5 / 22.5^{\circ} \mathrm{C}, \mathrm{d} / \mathrm{n}\right)$ compared to a lower temperature $\left(17.5 / 7.5^{\circ} \mathrm{C}, \mathrm{d} / \mathrm{n}\right)$ due to reduced absorption of glyphosate and reduced translocation of dicamba. Scientific literature is not existing on effect of temperature on efficacy of 2,4-D for control of 2,4-D-resistant and susceptible common waterhemp. Understanding the effect of temperature on efficacy of 2,4-D as a post-emergence option will help to better facilitate control of common waterhemp. The objectives of this research were (1) to evaluate the efficacy of 2,4-D on WHS and WHR control at a high $\left(\mathrm{HT} ; 34 / 20^{\circ} \mathrm{C}, \mathrm{d} / \mathrm{n}\right)$ and low $\left(\mathrm{LT} ; 24 / 10^{\circ} \mathrm{C}, \mathrm{d} / \mathrm{n}\right)$ temperature regimes, and (2) to investigate the uptake, translocation, and metabolism of ${ }^{14} \mathrm{C} 2,4-\mathrm{D}$ in WHS and WHR common waterhemp at aforementioned temperature regimes.

\section{Results}

2,4-D dose-response experiment. WHS and WHR exhibited varying response to 2,4-D at HT or LT regime (Fig. 1). At 4 WAT, the amount of 2,4-D required to reduce $50 \%\left(\mathrm{GR}_{50}\right)$ growth of WHS and WHR plants grown at HT regime were 178 and 3,696 $\mathrm{g} \mathrm{ae} \mathrm{ha}^{-1}$ and while at LT regime were 107 and 1,001 $\mathrm{g}$ ae ha ${ }^{-1}$, respectively (Table 1). Thus, the resistance indices of WHR relative to WHS grown at HT and LT regimes were $\sim 20$ and $\sim 10$, respectively, suggesting that WHR common waterhemp showed increased level of resistance to 2,4-D at HT compared to LT (Fig. 1, Table 1). "CompParm" function in R indicated that there is significant diference between $\mathrm{GR}_{50}$ of WHR at HT and LT $(\mathrm{p}<0.05)$, WHR and WHS at HT $(\mathrm{p}<0.01)$, WHR and WHS at LT $(\mathrm{p}<0.001)$. However, there was no significant difference between $\mathrm{GR}_{50}$ of WHS at HT and LT. This suggstes reduction in efficacy of 2,4-D at HT to control 2,4-D-resistant common waterhemp (Fig. 1).

The test for 'lack of fit' in 'drc' was non-significant $(\mathrm{p}=0.88)$, suggesting that the data fitted the regression model reasonably. Root means square error (RMSE) values of the 2,4-D dose-response experiments conducted at HT and LT ranged from 1.82 to 2.48 for WHS and 2.65 to 2.04 for WHS respectively, indicating a good fit.

${ }^{14} \mathrm{C}$ 2,4-D absorption and translocation experiment. Regression analysis of ${ }^{14} \mathrm{C} 2,4-\mathrm{D}$ absorption indicated that temperature did not affect the absorption or translocation of ${ }^{14} \mathrm{C} 2,4-\mathrm{D}$ in both WHS and WHR and there was no significant difference between $\mathrm{A}_{\max }$ (upper limit of absorption) and $\mathrm{A}_{90}$ (the time required to achieve $90 \%$ of maximum absorption) of WHR and WHS at HT and LT conditions. A $\mathrm{Amx}_{\max }$ for WHS and WHR at HT and LT regimes were $96.31( \pm 3.70), 92.73( \pm 3.61)$, and $93.43( \pm 2.54)$, and $95.35( \pm 3.16) \%$, respectively (Table 2$)$. 


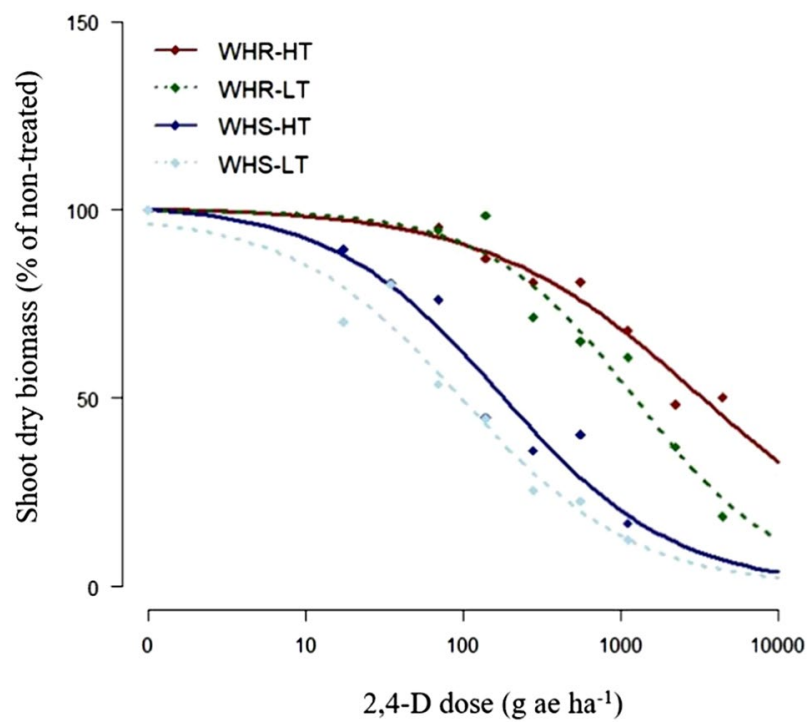

Figure 1. Whole-plant 2,4-D dose-response of 2,4-D susceptible (WHS) and -resistant common waterhemp (WHR) at low $\left(\mathrm{LT} ; 24 / 10^{\circ} \mathrm{C}, \mathrm{d} / \mathrm{n}\right)$ and high $\left(\mathrm{HT} ; 34 / 20^{\circ} \mathrm{C}, \mathrm{d} / \mathrm{n}\right)$ temperature regimes based on dry shoot biomass at 4 weeks after treatment (WAT).

\begin{tabular}{|c|c|c|c|c|c|}
\hline \multirow[b]{2}{*}{ Population } & \multirow[b]{2}{*}{ Temperature $\left({ }^{\circ} \mathrm{C}\right)$} & \multicolumn{2}{|l|}{ Absorption } & \multicolumn{2}{|l|}{ Translocation } \\
\hline & & $\mathbf{A}_{\max }$ & $\mathrm{A}_{90}$ & $\mathrm{~T}_{\max }$ & $\mathrm{T}_{90}$ \\
\hline \multirow{2}{*}{ WHS } & $24 / 10$ & $92.73( \pm 3.61)$ & $13( \pm 7.38)$ & $79.18( \pm 14.03)$ & $119.73( \pm 70.20)$ \\
\hline & $34 / 20$ & $96.31( \pm 3.70)$ & $18( \pm 6.19)$ & $75.69( \pm 14.39)$ & $111.63( \pm 55.07)$ \\
\hline \multirow{2}{*}{ WHR } & $24 / 10$ & $95.35( \pm 3.16)$ & $22.12( \pm 7.61)$ & $73.78( \pm 18.92)$ & $120.59( \pm 94.74)$ \\
\hline & $34 / 20$ & $93.43( \pm 2.54)$ & $16.43( \pm 5.17)$ & $70.83( \pm 14.39)$ & $113.12( \pm 77.17)$ \\
\hline
\end{tabular}

Table 2. Regression parameter estimates of ${ }^{14} \mathrm{C} 2,4$-D absorption and translocation of 2,4-D- susceptible (WHS) and -resistant (WHR) common waterhemp at low $\left(24 / 10^{\circ} \mathrm{C}, \mathrm{d} / \mathrm{n}\right)$ and high $\left(34 / 20^{\circ} \mathrm{C}, \mathrm{d} / \mathrm{n}\right)$ temperature regimes using rectangular hyperbola model. ${ }^{a}$ Data combined from two runs. ${ }^{b} \mathrm{~A}_{\max }$ and $\mathrm{T}_{\max }$ is the maximum absorption or translocation (\%), $\mathrm{A}_{90}$ or $\mathrm{T}_{90}$ is the time (h) required to achieve $90 \%$ of the maximum absorption or translocation. ${ }^{c}$ Values in parenthesis are standard error of mean.

Moreover, $\mathrm{A}_{90}$ was also similar in WHS and WHR plants at HT or LT regimes i.e., $18( \pm 6.19), 13( \pm 7.38), 16.43$ $( \pm 5.17)$, and $22.12( \pm 7.61)$ hours, respectively (Table 2$)$. Similarly, there was no significant difference between $\mathrm{T}_{\max }$ (upper limit of translocation) and $\mathrm{T}_{90}$ (the time required to achieve $90 \%$ of maximum translocation) between WHS and WHR at two temperature regimes, which indicated that temperature regimes did not affect ${ }^{14} \mathrm{C} 2,4-\mathrm{D}$ translocation. The predicted $\mathrm{T}_{\max }$ for WHS and WHR at HT and LT regimes were $75.69( \pm 14.39), 79.18( \pm 14.03)$ and $70.83( \pm 14.39)$, and $73.78( \pm 18.92) \%$, respectively (Table 2$)$. The time required to achieve $90 \%$ of the maximum translocation of 2,4-D in WHS and WHR plants were $111.63( \pm 55.07), 119.73( \pm 70.20)$ and 113.12 ( \pm 77.17$), 120.59$ ( \pm 94.74$)$ hours, respectively, at HT and LT regimes (Table 2).

${ }^{14} \mathrm{C}$ 2,4-D metabolism experiment. The HPLC chromatographs indicated that the retention time of the parent ${ }^{14} \mathrm{C} 2,4-\mathrm{D}$ (used as standard) was $11.96 \mathrm{~min}$ (Fig. 2). Peaks of parent 2,4-D were much taller in WHR at LT compared to HT at 24 and 72 HAT. However, such difference was not observed at 6 HAT in WHR plants (Fig. 3b) At 6 HAT, the mean 2,4-D retention by WHR and WHS common waterhemp at HT and LT temperature regimes was 69.3, 69.3\%, and 85.1, 95.3\%, respectively (Fig. 3a,b). Twenty-four HAT, WHR plants retained 20.2 and $47.7 \%$ of parent 2,4-D at HT (Figs 2d and 3b) and LT (Figs 2c, 3b), respectively. Whereas, WHS retained 82.3 (Figs $2 \mathrm{~b}$ and $3 \mathrm{a}$ ) at $\mathrm{HT}$ and 86.1 (Figs $2 \mathrm{a}$ and $3 \mathrm{a}$ ) \% at LT, respectively. This validates that, metabolism of 2,4-D plays a key role in bestowing 2,4-D resistance in WHR (Fig. 2). More importantly, this indicates that at 24 HAT, WHR plants grown at LT retained approximately $27 \%$ more parent 2,4-D than at HT (Figs $2 \mathrm{c}, \mathrm{d}$ and $3 \mathrm{~b}$ ). This indicates rapid metabolism of 2,4-D in WHR plants grown at HT compared to LT. Also, at $72 \mathrm{HAT}$, the WHR plants grown at HT conditions metabolized close to $100 \%$ of the parent $2,4-\mathrm{D}$ while those at LT still retained $9.4 \%$ (Fig. 3b). At 72 HAT the WHS plants retained $33.7,54.5 \%$ of parent 2,4-D at HT and LT conditions, respectively (Fig. 3a). Overall, the rate of 2,4-D metabolism increased both in WHR and WHS at HT (Fig. 3a,b).

The two-way analysis of parent $2,4-\mathrm{D}$ retained in WHR followed by mean comparison using $\operatorname{LSD}(\mathrm{p}=0.05)$ suggested that there is a significant difference in \% parent 2,4-D present in WHR at 24 HAT (Fig. 3b) with more 2,4-D being retained in plants grown at LT. In case of WHS plants, such difference was observed at 72 HAT (Fig. 3a) with more 2,4-D retained at LT compared to HT. 
(a)

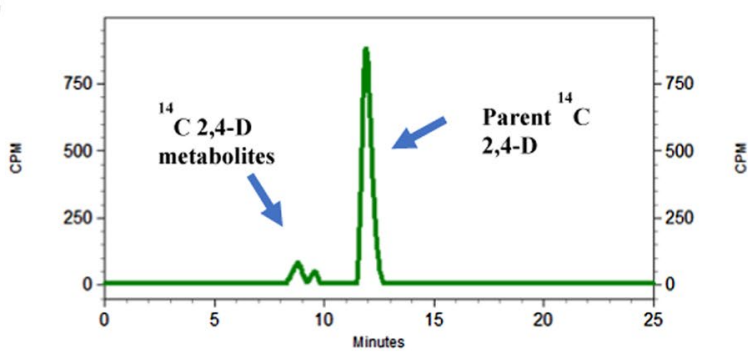

(c)

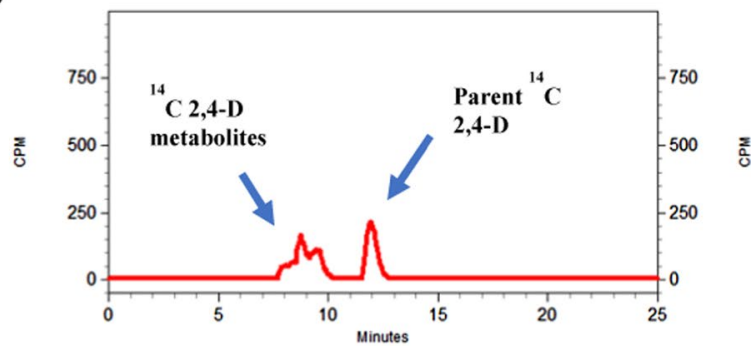

(b)

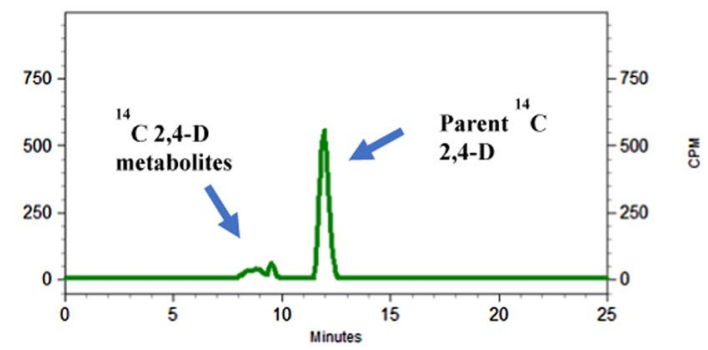

(d)

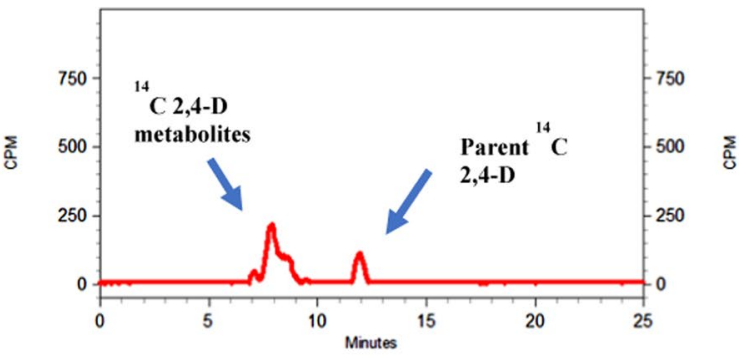

Figure 2. ${ }^{14} \mathrm{C}$ 2,4-D parent compound and its metabolites in (a,b) 2,4-D-susceptible (WHS) and (c,d) 2,4-D resistant (WHR) common waterhemp populations at 24 hours after treatment (HAT) at $(\mathbf{a}, \mathbf{c})$ low temperature regime $\left(24 / 10^{\circ} \mathrm{C}, \mathrm{d} / \mathrm{n}\right)$ and $(\mathbf{b}, \mathbf{d})$ high temperature regime $\left(34 / 20^{\circ} \mathrm{C}, \mathrm{d} / \mathrm{n}\right)$.

(a)

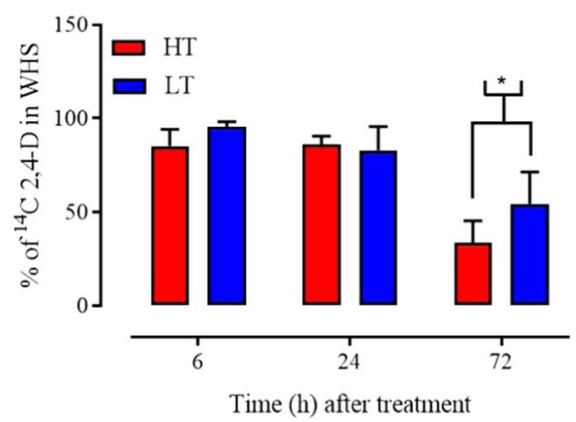

(b)

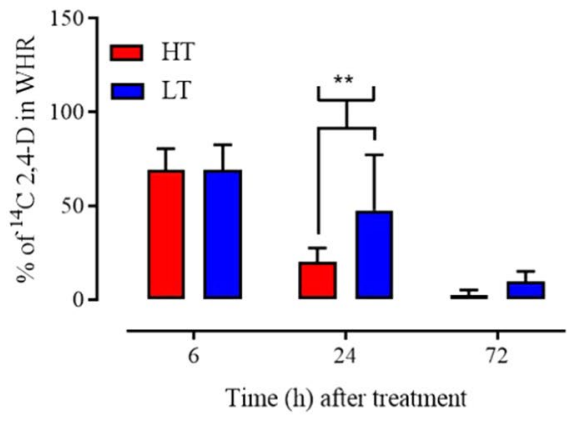

Figure 3. Percentage of ${ }^{14} \mathrm{C} 2,4$-D parent compound in (a) 2,4-D susceptible (WHS) and (b) resistant (WHR) common waterhemp populations at 6,24 , and 72 hours after treatment (HAT) at low (LT; $24 / 10^{\circ} \mathrm{C}$, $\mathrm{d} / \mathrm{n})$ and high $\left(\mathrm{HT} ; 34 / 20^{\circ} \mathrm{C}, \mathrm{d} / \mathrm{n}\right)$ temperature regimes. Data combined over two runs. $* \mathrm{P}$-value $<0.05$, $* * \mathrm{P}$-value $<0.001$, ***P-value $<0.0001$, indicates the level of significance of difference in means, and error bars represent standard error of mean).

\section{Discussions}

The time of emergence of common waterhemp under field conditions depends on various factors including, soil temperature, moisture, and seed dormancy. Especially, in the Midwestern United States, common waterhemp emergence occurs over a wider time frame compared to other summer annual weed species ${ }^{25}$. The average diurnal temperatures in May and July, the two-major seasons for waterhemp cohort emergence, are around $24 / 10^{\circ} \mathrm{C}$

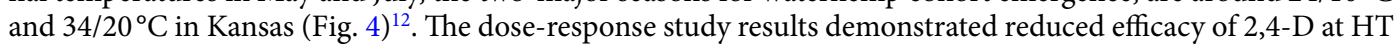
$\left(34 / 20^{\circ} \mathrm{C}\right)$ compared to LT $\left(24 / 10^{\circ} \mathrm{C}\right)$ for controlling both WHS and WHR common waterhemp. In contrast, Ganie et al. ${ }^{23}$ reported improved efficacy of 2,4-D or glyphosate at $\mathrm{HT}\left(29 / 17^{\circ} \mathrm{C}\right)$ compared with LT $\left(20 / 11^{\circ} \mathrm{C}\right)$ for common and giant ragweed control regardless of susceptibility or resistance to glyphosate. Godar et al. ${ }^{26}$ reported reduced efficacy of mesotrione for Palmer amaranth (Amaranthus palmeri) control at high $\left(40 / 30^{\circ} \mathrm{C}\right)$ compared to low $\left(25 / 15^{\circ} \mathrm{C}\right)$ temperature due to reduced translocation coupled with rapid metabolism of mesotrione and increased 4-hydroxyphenylpyruvate dioxygenase (HPPD)-gene expression. However, as previously reported by Figueiredo et al. ${ }^{6}$ the data from this study also showed no difference in 2,4-D absorption or translocation between WHR and WHS (Table 2). The maximum limit of ${ }^{14} \mathrm{C} 2,4$-D absorption in this study was found to be $95 \%$ in WHR and WHS common waterhemp (Table 2). Previous studies have shown that 2,4-D absorption can range from $10-99 \%$ depending on several factors such as environment, weed species and other application factors ${ }^{27}$. Similar to our findings, Coetzer et al. ${ }^{28}$ reported no effect of temperature on glufosinate absorption in Palmer amaranth. 


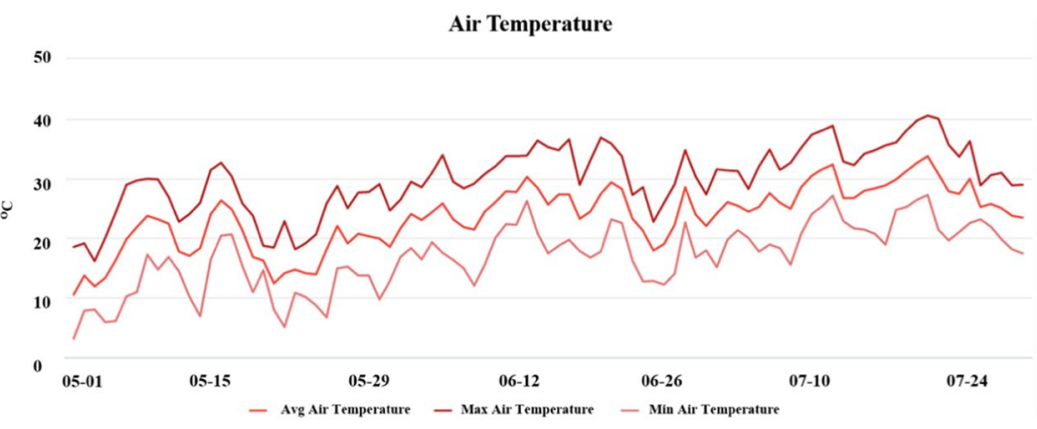

Figure 4. Average, maximum, and minimum air temperature in Kansas during May to July, a typical common waterhemp emergence time in the state (KSU, Mesonet 2018).

High temperature increased the rate of metabolism of 2,4-D both in WHR and WHS common waterhemp. Similar to these findings, Johnson and Young ${ }^{29}$, reported a 6-7-fold higher susceptibility of common waterhemp to mesotrione at $18^{\circ} \mathrm{C}$ compared to $32^{\circ} \mathrm{C}$. Likewise, Olsen et al. ${ }^{30}$ reported decreased metabolism of MON 37500 in several grass weeds (Aegilops cylindrica, Avena fatua, Bromus tectorum) grown at cool air temperature. Gallaher et al. ${ }^{31}$ observed rapid metabolism of primisulfuron and nicosulfuron in broadleaf signalgrass (Brachiaria platyphylla) at high $\left(30 / 20^{\circ} \mathrm{C}\right)$ compared to low $\left(20 / 10^{\circ} \mathrm{C}\right)$ temperature.

The auxinic herbicide-tolerant monocotyledonous weeds are known to metabolize 2,4-D via ring hydroxylation mediated by cytochrome P-450 monooxygenases, an enzyme family predominantly involved in metabolizing xenobiotics in plants ${ }^{16,32}$. A possible involvement of these enzymes in 2,4-D degradation has been documented in many dicotyledonous weeds, resistant to this herbicide. For example, cytochrome P-450 mediated 2,4-D degradation has been reported in 2,4-D-resistant corn poppy ${ }^{19}$. Figueiredo et al. ${ }^{6}$ reported a 7-fold reduction in $\mathrm{GR}_{50}$ of WHR (the same common waterhemp) with pre-treatment of malathion (a cytochrome P-450-inhibitor) followed by 2,4-D compared to plants treated with 2,4-D alone, indicating a possible involvement of cytochrome P-450s in 2,4-D metabolism in common waterhemp. Thus, it is likely that a rapid metabolism of 2,4-D in WHR plants grown at HT is facilitated by increased activity of cytochrome P-450 enzymes. Previously, Viger et al..$^{33}$ reported rapid metabolism of metolachlor at a high temperature $\left(30^{\circ} \mathrm{C}\right)$ compared to a low temperature $\left(21^{\circ} \mathrm{C}\right)$, which was associated with a five-fold increase in glutathione-S-transferase (GST) activity in corn. Therefore, the possible increased cytochrome P-450 enzyme activity may be an example of common waterhemp adaptation to high temperature stress. Studies have shown that plant response to stress, including abiotic stress can lead to further selection of resistant weed biotypes ${ }^{34}$. Hence, application of $2,4-\mathrm{D}$ at the most effective temperature regime is important to control common waterhemp and reduce further selection of 2,4-D resistance.

In conclusion, the results of this research demonstrate that 2,4-D efficacy can be improved at low temperature regime $\left(24 / 10^{\circ} \mathrm{C}, \mathrm{d} / \mathrm{n}\right)$ to manage common waterhemp. Thus, applying $2,4-\mathrm{D}$ when day temperature is lower than $30^{\circ} \mathrm{C}$ is desirable for common waterhemp control; however, apart from air temperature other abiotic factors such as light intensity, relative humidity, and plant factors such as leaf orientation also play key role in affecting herbicide efficacy. Our studies were conducted in growth chambers where apart from temperature all other factors were kept constant. This is particularly important to reduce common waterhemp competition and crop yield loss and reduce selection for resistance. In general, the efficacy of auxinic herbicides for controlling dicotyledonous weeds depends on several factors including time of application ${ }^{34-37}$. Additionally, efficacy of 2,4-D is species dependent as improved efficacy at HT has been noticed for control of common and giant ragweed. Therefore, further studies are needed to assess the interaction of other abiotic and plant factors that can influence 2,4-D efficacy for controlling common waterhemp.

\section{Materials and Methods}

Plant materials and growth conditions. WHS and WHR common waterhemp from Nebraska, USA were used in this study, . Common waterhemp resistant to 2,4-D (WHR) has been confirmed in a native grass little bluestem (Schizachyrium scoparium) production field in southeastern Nebraska where 2,4-D was applied for over 10 years $^{6}$. The susceptible population (WHS) was collected from a soybean field near Auburn, Nebraska ${ }^{3,6}$.

WHS and WHR common waterhemp seeds were germinated in plastic trays $(25 \times 15 \times 2.5 \mathrm{~cm})$ filled with potting mix (Fafard ${ }^{\circledR}$ ultra container potting mix, Sungro Horticulture, Agawam, MA). After emergence, individual seedlings at 2-3 leaf stage were transplanted into plastic pots $(6 \times 6 \times 6 \mathrm{~cm})$ and kept in the greenhouse maintained at $25 / 20^{\circ} \mathrm{C}$ day/night $(\mathrm{d} / \mathrm{n}), 15$ hours of photoperiod supplemented with $120 \mu \mathrm{mol} \mathrm{m}^{-2} \mathrm{~s}^{-1}$ illumination provided with sodium vapor lamps along with $60 \pm 10 \%$ relative humidity. At 7 days after transplanting, half of the small and uniform seedlings (4-leaf stage) were transferred in growth chambers set at $\mathrm{HT}\left(34 / 20^{\circ} \mathrm{C}, \mathrm{d} / \mathrm{n}\right.$ ) and the rest were transferred in a separate growth chamber set at LT $\left(24 / 10^{\circ} \mathrm{C}, \mathrm{d} / \mathrm{n}\right)$. Temperature regimes were selected based on the average diurnal temperatures during mid-May to mid-June in Kansas, USA ${ }^{12}$. Incandescent and fluorescent bulbs were used in growth chambers to maintain light level of $750 \mu \mathrm{mol} \mathrm{m} \mathrm{m}^{-2} \mathrm{~s}^{-1}(15 / 9 \mathrm{hrs}, \mathrm{d} / \mathrm{n}$ condition) and relative humidity was maintained at $60 \pm 10 \%$ throughout the study. Plants were watered daily and fertilized once a week after transplanting.

2,4-D dose-response experiment. Ten to $12 \mathrm{~cm}$ tall WHS and WHR common waterhemp plants grown at HT or LT were treated with several rates of 2,4-D (2,4-D Amine 4, Winfield Solutions, LLC, St. Paul MN, 
USA). Specifically, the WHS plants were treated at $0,17.5,35,70,140,560,1,120 \mathrm{~g}$ ae ha $\mathrm{h}^{-1} 2,4-\mathrm{D}$ whereas, the WHR plants were treated with $0,70,140,280,560,1,120,2,240,4,480 \mathrm{~g}^{2} \mathrm{ha}^{-1}$ 2,4-D, using a bench-type sprayer (Research Track Sprayer, Generation III, De Vries Manufacturing, Hollandale, MN, USA) equipped with a single flat-fan nozzle (80015LP TeeJet tip, Spraying Systems Co., Wheaton, IL, USA) delivering $187 \mathrm{~L} \mathrm{ha}^{-1}$ at $220 \mathrm{kPa}$ in a single pass at $3.2 \mathrm{~km} \mathrm{~h}^{-1}$. The treated plants were transferred back in respective growth chambers $30 \mathrm{~min}$ after 2,4-D application. At 4 weeks after treatment (WAT), above-ground biomass from each plant was harvested and placed in paper bags and dried in an oven at $60^{\circ} \mathrm{C}$ for 72 hours (h) to measure dry shoot biomass. Percent dry shoot biomass was calculated relative to the non-treated control for each common waterhemp population as follows:

$$
\text { Shoot biomass }(\%)=\frac{\text { biomass of each sample } \times 100}{\text { biomass of the non-treated sample }}
$$

${ }^{14} \mathrm{C}$ 2,4-D absorption and translocation experiment. WHS and WHR seedlings, raised and grown in the greenhouse (as described above) were transferred to growth chambers maintained at high (HT: $34 / 20^{\circ} \mathrm{C}$, $\mathrm{d} / \mathrm{n}$ ) and low (LT: $24 / 10{ }^{\circ} \mathrm{C}, \mathrm{d} / \mathrm{n}$ ) temperatures. ${ }^{14} \mathrm{C} 2,4$-D working solution was prepared by mixing ${ }^{14} \mathrm{C} 2,4-\mathrm{D}$ $\left[3.3 \mathrm{kBq}^{-1}\right.$ with a specific activity of $5.5 \mathrm{MBq} \mathrm{mmol}^{-1}$ (Dow AgroSciences, Indianapolis, IN, USA)] with commercially available 2,4-D (2,4-D Amine 4, Winfield Solutions, LLC, St. Paul MN, USA) to obtain $560 \mathrm{~g}^{2} \mathrm{ha}^{-1}$ 2,4 -D in a carrier volume of $187 \mathrm{~L}$. Ten to $12 \mathrm{~cm}$ tall ( 8 to10 leaf stage) plants were treated with ten $1-\mu$ d droplets of ${ }^{14} \mathrm{C} 2,4$-D working solution on the adaxial surface of the fourth youngest fully expanded leaf using Wiretrol ${ }^{\circledR}$ ( $10 \mu \mathrm{L}$; Drummond Scientific Co., Broomall, PA, USA). After 30 minutes, the treated plants were returned to respective growth chambers maintained at HT or LT. The plants were harvested at 6, 24, and 72 hours after treatment (HAT), and separated into treated-leaf (TL), tissue above treated-leaf (ATL), and below treated-leaf (BTL). TL were washed with $5 \mathrm{ml}$ of wash solution containing $10 \%(\mathrm{v} / \mathrm{v})$ aqueous solution of ethanol and $0.5 \%$ Tween-20 in 20-ml scintillation vials for 1 minute to remove excess unabsorbed 2,4-D from the leaf surface. The leaf rinsate was mixed with $15 \mathrm{ml}$ of scintillation cocktail [Ecolite-(R), MP Biomedicals, LLC. Santa Ana, CA, USA] to measure the radioactivity using liquid scintillation counter (LSC; Beckman Coulter LS6500 Liquid Scintillation Counter, Beckman Coulter Inc., Fullerton, CT, USA). Plant sections were oven dried at $60^{\circ} \mathrm{C}$ for $72 \mathrm{~h}$, and then combusted for 3 min using a biological oxidizer (OX-501, RJ Harvey Instrument, Tappan, NY, USA). The ${ }^{14} \mathrm{C}$ 2,4-D was recovered in a scintillation cocktail [Carbon-14 (C14) Cocktail, RJ Harvey Instrument, Tappan, NY, USA] and the radioactivity was measured using a LSC. The data was converted into percentages using the following equations ${ }^{26}$,

$$
\text { Percentage absorption (percent } \left.R_{\text {absorbed }}\right)=\frac{\left(R_{\text {applied }}-R_{\text {rinsate }}\right) \times 100}{R_{\text {applied }}}
$$$$
\text { Percentage translocation }=\left(100-\text { percent } R_{T L}\right)
$$

$$
\text { Percentage radoiactivity recovered in treated leaf }=\frac{R_{T L} \times 100}{R_{\text {absorbed }}}
$$

In the above equations, $\mathrm{R}_{\text {absorbed }}$ is the radioactivity absorbed; $\mathrm{R}_{\text {applied }}$ is total amount of radioactivity applied on the plant; $\mathrm{R}_{\text {rinsate }}$ is the radioactivity recovered in leaf rinsate; and $\mathrm{R}_{\mathrm{TL}}$ is the radioactivity recovered in the treated leaf (TL).

${ }^{14} \mathrm{C}$ 2,4-D Metabolism experiment. The WHS and WHR common waterhemp plants $(10-12 \mathrm{~cm}$ tall) grown under high and low temperature regimes (as described above) were used. The adaxial surface of the fourth youngest fully expanded leaf was treated with 10 - $\mu$ l droplets of ${ }^{14} \mathrm{C} 2,4$-D working solution containing ${ }^{14} \mathrm{C}$ $2,4-\mathrm{D}\left(5 \mathrm{kBqul}^{-1}\right.$ with a specific activity of $\left.5.5 \mathrm{MBq} \mathrm{mmol}^{-1}\right)$ and commercial $2.4-\mathrm{D}$ and plants were returned to growth chambers. Treated plants were harvested at 6, 24, and 72 HAT. At each harvest time, the TL was washed as described in absorption and translocation experiment to remove excess unabsorbed 2,4-D from the leaf surface. Above-ground plant tissue including the TL was wrapped in aluminum foil and flash frozen in liquid nitrogen to store at $-80{ }^{\circ} \mathrm{C}$. The frozen plant tissue was later grinded using a mortar and pestle. The ${ }^{14} \mathrm{C} 2,4-\mathrm{D}$, and its metabolites were extracted with $15 \mathrm{ml}$ of $90 \%$ aqueous acetone in a centrifuge tube and preserved at $4{ }^{\circ} \mathrm{C}$ for at least 16 hours. After 16 hours, the tubes were centrifuged at $5,000 \times \mathrm{g}$ for 10 minutes. The supernatant was transferred to a new centrifuge tube and concentrated at $45^{\circ} \mathrm{C}$ for $1.5-2 \mathrm{~h}$ with a rotary evaporimeter (Centrivap, Labconco, Kansas City, MO). The final volume of the supernatant was maintained around $600 \mu \mathrm{L}$ and transferred to a $1.5 \mathrm{ml}$ microcentrifuge tube and centrifuged at $10,000 \times \mathrm{g}$ for 10 minutes. The radioactivity of the supernatant solution was measured with the liquid scintillation counter and normalized by diluting the samples with $50 \%$ acetonitrile ( $1: 1 \mathrm{v} / \mathrm{v}$ acetonitrile:water). The final solutions were analyzed using reversed-phase high-performance liquid chromatography (HPLC) (BeckmanCoulter system Gold 126 solvent module, Beckman Coulter Inc., Fullerton, CA, USA) to resolve the solution contents into parent ${ }^{14} \mathrm{C} 2,4-\mathrm{D}$ and its metabolites.

Experimental design and statistical analysis. The experiments were arranged in a split-plot design with four replications and repeated in time. Growth chambers were switched between two experimental runs to avoid effect of growth chamber on plant response. The dose-response experiments were arranged in a two-way 
factorial combination of temperature regimes (HT and LT) as main factor and herbicide doses for each common waterhemp population as sub-plot factor.

Relative shoot biomass data obtained from the whole plant dose-response study were analyzed using the 'drc' package (drc 1.2, Christian Ritz and Jens Strebig, R2.5, Kurt Hornik, online) in R (R statistical software, R Foundation for Statistical Computing, Vienna, Austria; http://www.R-project.org) as per Knezevic et al. ${ }^{38} \mathrm{~A}$ dose-response regression model was constructed using the three-parameter log-logistic equation.

$$
Y=\left\{\frac{d}{1}+\exp [b(\log X-\log e)]\right\}
$$

In equation above, $\mathrm{Y}$ is response variable (\% reduction in biomass compared to control), $\mathrm{b}$ denotes relative slope around e, e is $\mathrm{GR}_{50}$ (effective dose to reduce biomass of the population by $50 \%$ ) and $\mathrm{d}$ is the upper limit of the model. The ratio of $\mathrm{GR}_{50}$ values of WHS and WHR common waterhemp in HT and LT conditions were calculated to determine the level of resistance or the resistance index. Estimated $\mathrm{GR}_{50}$ values were then compared with each other using the "compParm" function in 'drc' package in R.

Fitness of the log-logistic regression model used above was assessed through the "Lack-of-fit" test in 'drc' using "modelFit" function. Further, root mean square error (RMSE) was calculated to test the goodness of fit of the data. The formula used for RMSE ${ }^{25}$ was:

$$
R M S E=\left[\frac{1}{n} \sum_{i=1}^{n}\left(P_{i}-O_{i}\right)^{2}\right]
$$

where, $\mathrm{n}$ is the number of observations and $\mathrm{O}_{\mathrm{i}}$ and $\mathrm{P}_{\mathrm{i}}$ are the observed and predicted value of the observations respectively.

Absorption, translocation, and metabolism experiments, treatments were arranged in a two-way factorial combination with temperature regime (HT and LT) as the main-factor and harvesting time $(6,24$, and 72 HAT) as sub-factor for each common waterhemp population. The percentage of herbicide absorbed and translocated were used to fit asymptotic regression, rectangular hyperbola (RHB), and linear model according to Kniss et al. ${ }^{39}$ using 'drc' and ' $q P C R$ ' packages in R. After fitting the data to these three models, the bias-corrected Akaike information criteria (AICc) of each model was obtained and compared. For analyzing both 2,4-D absorption and translocation, the RHB model was selected due to the lowest AICc values. The RHB model used is:

$$
\begin{gathered}
\text { Absorption }=\frac{\left(A_{\max } \times t\right)}{\left[(10 / 90) \times A_{90}+t\right]} \\
\text { Translocation }=\frac{\left(T_{\max } \times t\right)}{\left[(10 / 90) \times T_{90}+t\right]}
\end{gathered}
$$

In the above equations, absorption is percent herbicide absorbed expressed in terms of percentage herbicide applied to the plant, $A_{\max }$ is the maximum herbicide absorption in time $t$, and $A_{90}$ is the time required for $90 \%$ of the absorption to occur. Similarly, translocation is the percent herbicide translocated expressed in terms of percentage herbicide absorbed in the plant, $\mathrm{T}_{\max }$ is the maximum herbicide translocation in time $t$, and $\mathrm{T}_{90}$ is the time required for $90 \%$ of the translocation to occur. $A_{\max }, A_{90}, T_{\max }$, and $T_{90}$ parameters of WHR and WHS at each temperature regime were compared using the "compParm" function in the 'drc' package.

In metabolism experiments, chromatographs obtained from HPLC profiling were used for visual assessment of ${ }^{14} \mathrm{C} 2,4-\mathrm{D}$ degradation. Percent parent ${ }^{14} \mathrm{C} 2,4-\mathrm{D}$ present in each sample was determined and analyzed using GraphPad Prism $7.04^{\circledR}$ (GraphPad Software, San Diego, CA) at $\mathrm{p}=0.05$ and comparisons were made between HT and LT conditions in each biotype.

Received: 19 March 2019; Accepted: 23 October 2019;

Published online: 13 November 2019

\section{References}

1. Bensch, C. N., Hoprak, M. J. \& Peterson, D. Interference of redroot pigweed (Amaranthus retroflexus), Palmer amaranth (A. palmeri), and common waterhemp (A. rudis) in soybean. Weed Sci. 51, 37-43 (2003).

2. Steckel, L. E. \& Sprague, C. L. Common waterhemp (Amaranthus rudis) interference in corn. Weed Sci. 52, 359-364 (2004).

3. Bernards, M. L., Crespo, R. J., Kruger, G. R., Gaussoin, R. \& Tranel, P. J. A waterhemp (Amaranthus tuberculatus) population resistant to 2,4-D. Weed Sci. 60, 379-384 (2012).

4. Heap, I. The International survey of herbicide resistant weeds. Online. Internet. Monday, December 24. Available, www.weedscience. org (2018).

5. Shergill, L. S., Barlow, B. R., Bish, M. D. \& Bradley, K. W. Investigations of 2,4-D and multiple herbicide resistance in a Missouri waterhemp (Amaranthus tuberculatus) population. Weed Sci. 66, 386-394 (2018).

6. Figueiredo, M. R. A. et al. Metabolism of 2,4-dichlorophenoxyacetic acid contributes to resistance in a common waterhemp population (Amaranthus tuberculatus) population. Pest Manag. Sci. 74, 2356-2362, https://doi.org/10.1002/ps.4811 (2018).

7. Wu, C. \& Owen, M. D. K. When is the best time to emerge: Reproductive phenology and success of natural common waterhemp (Amaranthus rudis) cohorts in the Midwest United States? Weed Sci. 62, 107-117 (2014).

8. Hartzler, R. G., Battles, B. A. \& Nordby, D. Effect of common waterhemp (Amaranthus rudis) emergence date on growth and fecundity in soybean. Weed Sci. 52, 242-245 (2004).

9. Jhala, A. J., Sandell, L. D., Sarangi, D., Kruger, G. R. \& Knezevic, S. Z. Control of glyphosate-resistant common waterhemp (Amaranthus rudis) in glufosinate-tolerant soybean. Weed Technol. 31, 32-45 (2017). 
10. Sarangi, D. et al. Pollen-mediated gene flow from glyphosate-resistant common waterhemp (Amaranthus rudis Sauer): consequences for dispersal of resistance genes. Nature Sci. Rep. 7, 44913 (2017).

11. Uscanga-Mortera, E., Clay, S. A., Forcella, E. \& Gunsolus, J. Common waterhemp growth and fecundity as influenced by emergence date and competing crop. Agron. J. 99, 1265-1270 (2007).

12. KSU Mesonet. Average air temperature, max air temperature and minimum air temperature in Kansas during the common waterhemp emergence time, http://mesonet.ksu.edu (2018).

13. Guo, P. \& Al-Khatib, K. Temperature effects on germination and growth of redroot pigweed (Amaranthus retroflexus), Palmer amaranth (A.palmeri), and common waterhemp (A. rudis). Weed Sci. 51, 869-875 (2003).

14. Coetzer, E., Al-Khatib, K. \& Peterson, D. E. Glufosinate efficacy on Amaranthus species in glufosinate-resistant soybeans. Weed Technol. 16, 326-331 (2002).

15. Munro, I. C. et al. A comprehensive, integrated review and evaluation of the scientific evidence relating to the safety of the herbicide 2,4-D. J. Am. Coll. Toxicol. 11, 560-664 (1992).

16. Peterson, M. A., McMaster, S. A., Riechers, D. E., Skelton, J. \& Stahlman, P. W. 2,4-D past, present, and future: A review. Weed Technol. 30, 303-345 (2016).

17. Schroder, P. \& Collins, C. Conjugating enzymes involved in xenobiotic metabolism of organic xenobiotics in plants. Intl. J. Phytoremediation 4, 247-265 (2002)

18. Montgomery, M. L., Chang, Y. L. \& Freed, V. H. Comparative metabolism of 2,4-D by bean and corn plants. J. Agric. Food Chem. 19, 1219-1221 (1971).

19. Torra, J. et al. Enhanced 2,4-D metabolism in two resistant Papaver rhoeas populations from Spain. Front. Plant Sci. 8, 1584 (2017).

20. Rey-Caballero, J. et al. Unravelling the resistance mechanisms to 2,4-D (2,4-dichlorophenoxyacetic acid) in corn poppy (Papaver rhoeas). Pest Biochem. Physiol. 133, 67-72 (2016).

21. Riar, D. S., Burke, I. C., Yenish, J. P., Bell, J. \& Gill, K. Inheritance and physiological basis of 2,4-D resistance in prickly lettuce (Lactuca serriola L.). J. Agric. Food Chem. 59, 9417-9423 (2011).

22. Goggin, D. E., Cawthray, G. R. \& Powles, S. B. 2,4-D resistance in wild radish: reduced herbicide translocation via inhibition of cellular transport. J. Exp. Bot. 11, 3223-3235 (2016).

23. Ganie, Z., Jugulam, M. \& Jhala, A. J. Temperature influences efficacy, absorption, and translocation of 2,4-D or glyphosate in glyphosate-resistant and glyphosate-susceptible common ragweed (Ambrosia artemisiifolia) and giant ragweed (Ambrosia trifida). Weed Sci. 65, 588-602 (2017).

24. Ou, J., Stahlman, P. W. \& Jugulam, M. Reduced absorption of glyphosate and decreased translocation of dicamba contribute to poor control of kochia (Kochia scoparia) at high temperature. Pest Manag. Sci., https://doi.org/10.1002/ps.4463 (2016).

25. Roman, E. S., Murphy, S. D. \& Swanton, C. J. Simulation of Chenopodium album seedling emergence. Weed Sci. 48, 217-224 (2000).

26. Godar, A. S. et al. Physiological and molecular mechanisms of differential sensitivity of Palmer amaranth (Amaranthus palmeri) to mesotrione at varying growth temperatures. PLoS ONE 10, 2012673 (2015).

27. Shergill, L. S., Bish, M. D., Jugulam, M. \& Bradley, K. W. Molecular and physiological characterization of six-way resistance in Amaranthus tuberculatus var. rudis biotype from Missouri. Pest Manag. Sci. 74, 2688-2698 (2018).

28. Coetzer, E., Al-Khatib, K. \& Loughin, T. M. Glufosinate efficacy, absorption, and translocation in amaranth as affected by relative humidity and temperature. Weed Sci. 49, 8-13 (2001).

29. Johnson, B. C. \& Young, B. G. Influence of temperature and relative humidity on the foliar activity of mesotrione. Weed Sci. 50, $157-161(2002)$

30. Olsen, B. L. S., Al-Khatib, K., Stahlman, P. \& Isakson, P. J. Efficacy and metabolism of MON 37500 in Triticum aestivum and weedy grass species as affected by temperature and soil moisture. Weed Sci. 48, 541-548 (2000)

31. Gallaher, K., Mueller, T. C., Hayes, R. M., Schwartz, O. \& Barrett, M. Absorption, translocation, and metabolism of primisulfuron and nicosulfuron in broadleaf signalgrass (Brachiaria platyphylla) and corn. Weed Sci. 47, 8-12 (1999).

32. Hatzios, K., Hock, B. \& Elstner, E. Metabolism and elimination of toxicants. Pages $469-518$ in Plant Toxicology. 4th edn. Boca Raton, FL: CRC Press (2005).

33. Viger, P. R., Eberline, C. V., Fuerst, E. P. \& Gronwald, J. W. Effects of CGA-154281 and temperature on metolachlor absorption and metabolism, glutathione content, and glutathione-S-transferase activity in corn (Zea mays). Weed Sci. 39, 324-328 (1991).

34. Dyer, W. E. Stress-induced evolution of herbicide resistance and related pleiotropic effects. Pest Manag. Sci. 74, 1759-1768 (2018).

35. Johnston, C. R., Eure, P. M., Grey, T. L. \& Culpepper, A. S. Time of application influences translocation of auxinic herbicides in Palmer amaranth. Weed Sci. 66, 4-14 (2018).

36. Stewart, C. L., Nurse, R. E. \& Sikkema, P. H. Time of day impacts postemergence weed control in corn. Weed Technol. 23, 346-355 (2009).

37. Skuterud, R., Bjugstad, N., Tyldum, A. \& Tørresen, K. S. Effect of herbicides applied at different times of the day. Crop Prot. 17, 41-46 (1998).

38. Knezevic, S. Z., Streibig, J. C. \& Ritz, C. Utilizing R software package for dose-response studies: the concept and data analysis. Weed Technol. 21, 840-848 (2007).

39. Kniss, A. R., Vassios, J. D., Nissen, S. J. \& Ritz, C. Nonlinear regression analysis of herbicide absorption studies. Weed Sci. 59, 601-610 (2011)

\section{Acknowledgements}

We acknowledge the support of Dow Agrosciences for providing ${ }^{14} \mathrm{C} 2,4-\mathrm{D}$ for conducting the experiment. We are also grateful to Dr. Junjun Ou for providing technical help during the course of experimentation and Dr. Sushila Chaudhuri for providing comments on improving the manuscript and helping with statistical analysis. This manuscript is approved for publication as Kansas Agricultural Experiment Station Contribution no 20-086-J. Publication of this article was funded in part by the Kansas State University Open Access Publishing Fund.

\section{Author contributions}

C.S., A.J.J., G.K. and M.J. conceived the research plan, C.S. conducted the experiments and statistical analysis, C.S. and, M.J. wrote the article with contributions from A.J.J. and G.K.

\section{Competing interests}

The authors declare no competing interests.

Additional information

Correspondence and requests for materials should be addressed to M.J.

Reprints and permissions information is available at www.nature.com/reprints. 
Publisher's note Springer Nature remains neutral with regard to jurisdictional claims in published maps and institutional affiliations.

(c) (i) Open Access This article is licensed under a Creative Commons Attribution 4.0 International License, which permits use, sharing, adaptation, distribution and reproduction in any medium or format, as long as you give appropriate credit to the original author(s) and the source, provide a link to the Creative Commons license, and indicate if changes were made. The images or other third party material in this article are included in the article's Creative Commons license, unless indicated otherwise in a credit line to the material. If material is not included in the article's Creative Commons license and your intended use is not permitted by statutory regulation or exceeds the permitted use, you will need to obtain permission directly from the copyright holder. To view a copy of this license, visit http://creativecommons.org/licenses/by/4.0/.

(c) The Author(s) 2019 